\title{
Perbedaan Kinerja Guru Bimbingan dan Konseling dalam Menyelenggarakan Konseling Individual Ditinjau dari Latar Belakang Pendidikan dan Pengalaman Bekerja
}

\author{
Muya Barida*, Alif Muarifah \\ Program Studi Bimbingan dan Konseling, Fakultas Keguruan dan Ilmu Pendidikan, \\ Universitas Ahmad Dahlan, Jl. Pramuka No. 42, Yogyakarta, Daerah Istimewa Yogyakarta, Indonesia 55161 \\ *Penulis koresponden, e-mail: muya.barida@bk.uad.ac.id
}

Artikel diterima: 18 Desember 2018; direvisi: 31 Maret 2019; disetujui: 31 Maret 2019

\begin{abstract}
The particular study aimed to determine the differences performance between school counselors in organizing individual counseling services in schools in terms of educational background and work experience. The research approach was descriptive survey through a descriptive comparative study design. The subjects were school counselor in Daerah Istimewa Yogyakarta, especially at Bantul Regency. The data analysis technique used two way ANOVA. Based on the statistical tests, the educational background and work experience did not significantly affect the performance of school counselors in providing individual counseling services in schools.
\end{abstract}

Keywords: performance; counseling; educational background; work experience; school counselor

\begin{abstract}
Abstrak: Penelitian ini bertujuan untuk mengetahui perbedaan kinerja guru Bimbingan dan Konseling (BK) dalam menyelenggarakan layanan konseling individual di sekolah ditinjau dari latar belakang pendidikan dan pengalaman bekerja. Pendekatan penelitian dengan descriptive survey melalui rancangan descriptive comparative study. Subjek penelitian ini adalah guru BK di Daerah Istimewa Yogyakarta (DIY), khususnya Kabupaten Bantul. Teknik analisis menggunakan rumus two way ANOVA. Berdasarkan hasil uji statistik diketahui bahwa latar belakang pendidikan dan pengalaman bekerja tidak berpengaruh secara signifikan terhadap kinerja Guru BK dalam menyelenggarakan layanan konseling individual di sekolah.
\end{abstract}

Kata kunci: kinerja; konseling; latar belakang pendidikan; pengalaman kerja; guru BK

\section{PENDAHULUAN}

Guru BK sebagai pemimpin dan manajer dalam layanan BK mempunyai peran dan tanggung jawab yang strategis terhadap keberhasilan pencapaian tujuan siswa (Cronin, 2018; Epstein \& Van Voorhis, 2010). Peran dan tanggung jawab tersebut menuntut guru BK untuk menunjukkan kinerja yang profesional. Sebuah penelitian menyebutkan bahwa guru BK lebih banyak melakukan layanan responsif, yaitu konsultasi dan konseling (Studer, Diambra, Breckner, \& Heidel, 2011; Yuksel-Sahin, 2009).

Di sekolah, guru BK lebih banyak melakukan konseling individual (Neukrug, 2011). Porsi pemberian konseling yang besar ini rentan terhadap profesionalitas guru BK, baik dalam perencanaan, pelaksanaan, maupun evaluasi layanan. Beberapa guru BK pada saat tahap perencanaan tidak melalui kegiatan assessment sebagai bahan masukan bagi penyusunan program layanan, dan hanya menyalin program layanan BK dari sekolah lain dan hasil pelatihan musyawarah guru BK atau menggunakan program BK pada tahun sebelumnya tanpa ada evaluasi program untuk perbaikan tahun depan (Purwanto, Rosra, \& Yusmansyah, 2014). Pada tahap implementasi kegiatan layanan, layanan konseling individual dilaksanakan hanya bagi siswa bermasalah yang dikirim oleh guru mata pelajaran atau wali kelas tanpa adanya inisiasi untuk aktif melakukan pendekatan kepada siswa. Selain itu, guru BK menerapkan teknik

Cara mengutip: Barida, M., \& Muarifah, A. (2019). Perbedaan Kinerja Guru Bimbingan dan Konseling dalam Menyelenggarakan Konseling Individual Ditinjau dari Latar Belakang Pendidikan dan Pengalaman Bekerja. Jurnal Kajian Bimbingan dan Konseling, 4(1), 22-29. https:// doi.org/10.17977/um001v4i12019p022 
yang masih konvensional, serta jarang menggunakan dan mengembangkan teknik-teknik pendekatan konseling individual modern. Guru BK juga kurang maksimal dalam melakukan kolaborasi dengan orang tua; wali kelas; guru mata pelajaran; dan pihak terkait di luar sekolah. Guru BK terkadang masih bersandar pada paradigma: BK sebagai layanan pendidikan yang lebih didasarkan atas tuntutan formal, sehingga guru BK lebih dihayati sebagai pengambil data siswa atau pekerja administrasi (Sugiharto, 2001).

Agar tujuan sekolah dapat tercapai, guru BK sebaiknya berkolaborasi dengan guru lain (Kozlowski, 2013; Mayes, Dollahide, \& Young, 2018; Rock, Remley, \& Range, 2017). Kolaborasi guru BK dengan guru akan meningkatkan prestasi akademik siswa dan menutup kesenjangan prestasi antar siswa. Kerjasama guru dan guru BK juga akan membantu siswa untuk membuat pilihan-pilihan karier yang lebih realistis (Munro, 2007), serta memenuhi kebutuhan sekolah dan para siswa (Sherwood, 2010). Oleh karena itu, guru harus diberikan pemahaman umum tentang tujuan program konseling, peran dan tanggung jawab guru BK (Joy, Hesson, \& Harris, 2011). Kerjasama dalam layanan BK antara guru BK dengan guru di sekolah juga dapat meningkatkan kemampuan siswa untuk memahami diri mereka dan mengembangkan kemampuan diri.

Guru BK hendaknya membuat suatu perencanaan untuk memanfaatkan pihak lain dalam aktivitas perkembangan karier agar memajukan kesuksesan akademik siswa. Kerja sama dengan pihak lain ini sangat bermanfaat terutama dalam layanan perencanaan dan peminatan. Dalam kerjasama layanan konseling individual bagi peningkatan keefektifan konseling dengan pihak lain, pihak lain selaku stakeholder mampu menjadi jembatan karier bagi kemajuan performa akademik siswa (Olguin \& Keim, 2009).

Banyaknya guru BK yang bukan berlatar belakang pendidikan Sarjana BK juga berpengaruh dalam pelaksanaan pemberian layanan (Jumail, 2013). Keadaan tersebut menimbulkan hambatan dalam pengetahuan konsep dan teknik untuk melaksanakan konseling kepada siswa. Sebagai dampak dari hambatan ini, siswa tidak suka untuk berbagi permasalahan mereka kepada guru BK. Hal ini sangat kontras dengan deskripsi bahwa guru BK sebagai pendidik yang sangat terlatih dalam latar pendidikan di tingkat Sekolah Dasar; Sekolah Menengah Pertama; dan Sekolah Menengah Atas yang menjunjung tinggi standar etis dan profesional untuk mendesain, mengimplementasikan, dan mengatur program layanan konseling komprehensif berdasarkan hasil yang menunjukkan dan meningkatkan keberhasilan siswa (ASCA, 2008). Dari deskripsi tersebut, dapat diketahui bahwa ada hubungan yang kuat antara layanan konseling dengan latar belakang pendidikan guru BK. Semakin relevan latar belakang pendidikan guru BK, maka seharusnya semakin baik pula kualitas layanan konseling yang dilaksanakan.

Semakin lama seseorang bekerja, seharusnya semakin baik pula kualitas kerjanya (Pankhurst, 2010). Apabila mengikuti hukum perkembangan, secara ideal semakin lama guru BK bekerja, maka semakin baik pula layanan yang dilaksanakan. Akan tetapi, di lapangan siswa-siswa cenderung merasa lebih nyaman dengan guru BK yang usianya tidak terpaut jauh dengan mereka (Hayslip Jr, Schneider, \& Shore, 1993). Guru BK yang terbilang senior tidak begitu aktif untuk mempraktikkan pendekatan dan teknik konseling modern/postmodern dibandingkan dengan guru BK junior.

Berdasarkan fenomena dan hasil penelitian yang telah dibahas, penulisan artikel ini bertujuan untuk mengetahui adanya perbedaan kinerja guru BK dalam menyelenggarakan layanan konseling individual di sekolah ditinjau dari latar belakang pendidikan dan pengalaman bekerja sebagai guru BK.

\section{METODE}

Penelitian kuantitatif ini menggunakan descriptive survey melalui rancangan descriptive comparative study (Lodico, Spaulding, \& Voegtle, 2010). Penelitian ini menggambarkan pengaruh dua variabel terhadap satu variabel. Variabel yang berpengaruh adalah pengalaman kerja sebagai guru BK dan latar belakang pendidikan guru BK. Variabel yang dipengaruhi yaitu kinerja guru BK dalam menyelenggarakan layanan konseling individual di sekolah.

Subjek penelitian ini adalah 30 guru BK di Kota Yogyakarta yang tergabung dalam Musyawarah Guru Bimbingan dan Konseling (MGBK) Daerah Istimewa Yogyakarta dan dipilih menggunakan teknik simple random sampling (Leedy \& Ormrod, 2005). Penelitian ini menggunakan instrumen inventori selfevaluation dan peer-evaluation kinerja konselor dalam menyelenggarakan layanan konseling individual di sekolah (Barida \& Sutarno, 2016). 
Analisis data menggunakan teknik analisis statistik Two Way ANOVA dengan bantuan program SPSS 21.0 for Windows. Peneliti membandingkan rata-rata nilai kinerja guru BK dalam menyelenggarakan layanan konseling individual di sekolah dari hasil pengisian instrumen inventori self-evaluation dan peer-evaluation kinerja konselor berdasarkan latar belakang pendidikan dan pengalaman kerja sebagai konselor (Barida \& Sutarno, 2018).

Pengalaman kerja guru BK dibagi menjadi lima interval yaitu: 1-7 tahun; 8-14 tahun; 15-21 tahun; 22-28 tahun; dan 29-35 tahun. Pembagian ini didasarkan pada pengalaman kerja yang paling lama (paling senior) hingga pengalaman kerja yang paling singkat (paling junior). Latar belakang pendidikan dibagi menjadi dua, yaitu guru BK yang memiliki latar belakang pendidikan bimbingan dan konseling atau psikologi pendidikan dan bimbingan, serta guru BK yang memiliki latar belakang pendidikan bukan bimbingan dan konseling atau psikologi pendidikan dan bimbingan.

Hipotesis yang diajukan yaitu: $\mathrm{H}_{\mathrm{o}}=$ Tidak ada perbedaan kinerja konselor dalam layanan konseling individual di sekolah berdasarkan pengalaman kerja dan latar belakang pendidikan; $\mathrm{H}_{1}=$ Ada perbedaan kinerja konselor dalam layanan konseling individual di sekolah berdasarkan pengalaman kerja dan latar belakang pendidikan. Apabila nilai signifikansi atau probabilitas kurang dari $0,05(<0,05)$ maka dapat dinyatakan $\mathrm{H}_{\mathrm{o}}$ ditolak, apabila nilai signifikansi atau probabilitas lebih dari $0,05(>0,05)$ maka dapat dinyatakan $\mathrm{H}_{\mathrm{o}}$ diterima.

\section{HASIL}

Hasil rata-rata kinerja konselor dalam menyelenggarakan layanan konseling individual berdasarkan pengalaman kerja dan latar belakang pendidikan guru BK disajikan pada tabel 1. Mengacu pada tabel 1, dapat diketahui nilai rata-rata kinerja konselor dalam menyelenggarakan layanan konseling individual yang memiliki latar belakang pendidikan BK lebih besar daripada yang tidak memiliki latar belakang pendidikan BK. Selanjutnya, untuk mengetahui apakah perbedaannya signifikan, dilakukan uji hipotesis melalui Two Way ANOVA yang hasilnya disajikan pada tabel 2. Dari tabel 2, dapat diketahui nilai-nilai penting:

\section{Corrected Model}

Adanya pengaruh semua variabel independen (pengalaman bekerja; latar belakang pendidikan dan interaksi pengalaman bekerja dengan latar belakang pendidikan atau "pengalaman pendidikan") secara bersama-sama terhadap variabel dependen (kinerja konselor). Hasil signifikansi adalah 0,235 $>0,05$ (Alfa) berarti model tidak valid.

\section{Intercept}

Adanya nilai perubahan variabel dependen (kinerja konselor) tanpa perlu dipengaruhi keberadaan variabel independen (pengalaman bekerja; latar belakang pendidikan dan interaksi pengalaman bekerja dengan latar belakang pendidikan atau "pengalaman pendidikan"), artinya tanpa ada pengaruh variabel independen, variabel dependen dapat berubah nilainya. Hasil signifikansi adalah 0,000 <0,05 (Alfa) berarti intercept signifikan.

Tabel 1. Nilai Rata-rata Kinerja Guru BK dalam Menyelenggarakan Konseling Individual

\begin{tabular}{cccc}
\hline No. & $\begin{array}{c}\text { Durasi kerja } \\
\text { (dalam tahun) }\end{array}$ & $\begin{array}{c}\text { Rata-rata nilai Guru BK } \\
\text { berlatar belakang S1 BK }\end{array}$ & $\begin{array}{c}\text { Guru BK berlatar belakang S1 } \\
\text { Non BK }\end{array}$ \\
\hline 1 & $1-7$ & 120,333 & 134,5 \\
2 & $8-14$ & 119,833 & 132 \\
3 & $15-21$ & 133,5 & 116,25 \\
4 & $22-28$ & 130,167 & 130,75 \\
5 & $29-35$ & 131,583 & 121,375 \\
Rata-rata & 125,5 & 128,13 \\
\hline
\end{tabular}


Tabel 2. Hasil Analisis Pengalaman Bekerja dan Pendidikan terhadap Kinerja Konselor

\begin{tabular}{lccccc}
\hline \begin{tabular}{l} 
Dependent Variable: Kinerja Konselor \\
\multicolumn{1}{c}{ Source }
\end{tabular} & Type III Sum of Squares & Df & Mean Square & F & Sig. \\
\hline $\begin{array}{l}\text { Corrected } \\
\text { Model }\end{array}$ & $1135,021 \mathrm{a}$ & 9 & 126,113 & 1,444 & 0,235 \\
Intercept & 387278,820 & 1 & 387273,820 & 4435,756 & 0,000 \\
Pengalaman & 88,415 & 4 & 22,104 & 0,253 & 0,904 \\
Pendidikan & 0,070 & 1 & 0,070 & 0,001 & 0,978 \\
Pengalaman & 973,017 & 4 & 234,254 & 2,683 & 0,061 \\
Pendidikan & 1746,146 & 20 & 87,307 & & \\
Error & 488022,000 & 30 & & & \\
Total & 2881,167 & 29 & & & \\
Corrected Total & & & & & \\
$\boldsymbol{R}$ Squared $=\mathbf{0 , 3 9 4}$ (Adjusted $\boldsymbol{R}$ Squared) $=\mathbf{0 , 1 2 1}$ & & & & \\
\hline
\end{tabular}

\section{Pengalaman Bekerja}

Hasil signifikansi adanya pengaruh pengalaman bekerja terhadap kinerja konselor di dalam model adalah 0,904 $>0,05$ (Alfa), berarti pengalaman bekerja tidak berpengaruh secara signifikan terhadap kinerja konselor.

\section{Latar Belakang Pendidikan}

Hasil signifikansi adanya pengaruh latar belakang pendidikan terhadap kinerja konselor di dalam model adalah 0,978 $>0,05$ (Alfa) berarti latar belakang pendidikan tidak berpengaruh secara signifikan terhadap kinerja konselor.

\section{Pengalaman bekerja dan Pendidikan}

Hasil signifikansi adanya pengaruh pengalaman bekerja dan pendidikan terhadap kinerja konselor di dalam model adalah 0,061 >0,05 (Alfa), berarti pengalaman bekerja dan pendidikan tidak berpengaruh secara signifikan.

\section{R Squared}

Adanya nilai determinasi berganda semua variabel independen dengan dependen. Hasil adalah 0,394 di mana jauh dari nilai 1 , berarti korelasi tidak kuat dan hanya menjelaskan kinerja konselor sebesar $12,1 \%$

\section{PEMBAHASAN}

Mengacu pada kerangka sosok utuh kompetensi konselor (ABKIN, 2007), kinerja konselor antara lain dapat diuraikan sebagai berikut: (1) perencanaan layanan konseling individual, yang mencakup: menganalisis kebutuhan siswa terhadap layanan konseling individual dan menyusun rencana layanan konseling individual yang berkelanjutan berdasarkan kebutuhan siswa secara komprehensif dengan pendekatan perkembangan; (2) pelaksanaan layanan konseling individual, yang mencakup: melaksanakan rencana layanan konseling individual; melaksanakan pendekatan kolaboratif dalam layanan konseling individual; dan memfasilitasi perkembangan pribadi; sosial; akademik; dan karier siswa; serta mengelola sarana rencana layanan konseling individual; dan (3) evaluasi layanan konseling individual, yang mencakup: melakukan evaluasi proses layanan konseling individual, dan evaluasi hasil layanan konseling individual. Hasil evaluasi tersebut dapat menjadi dasar untuk mengembangkan kompetensi profesional konselor.

Konseling merupakan hubungan profesional yang mendorong individu; keluarga; dan kelompok untuk menyempurnakan tujuan-tujuan kesehatan mental; keadaan yang baik; pendidikan; dan karier (Neukrug, 2011). Upaya untuk menetapkan tujuan pelaksanaan konseling terlihat mudah, namun cukup 
rumit. Geldard \& Geldard (2009) mengidentifikasikan tujuan konseling, yaitu: tujuan dasar; tujuan orangtua; tujuan konselor; dan tujuan anak/siswa. Tujuan layanan konseling tidak kaku, tergantung pada suatu kebutuhan tertentu. Tujuan dari konseling antara lain: (1) konseli mampu memahami diri, potensi, kelebihan, kelemahan, serta lingkungannya; (2) konseli mampu menyesuaikan diri, potensi, kelebihan, dan kelemahannya sesuai perubahan atau kebutuhan perkembangan lingkungan; (3) konseli mampu mengarahkan diri, potensi, dan kelebihannya terhadap hal-hal yang produktif; (4) konseli mampu mengembangkan diri, potensi, dan kelebihannya terhadap pencapaian yang lebih optimal, dan (5) konseli mampu memperbaiki atau mengatasi kelemahannya sehingga mampu mencapai keadaan yang baik dan positif.

Guru BK secara aktif berpartisipasi dalam pencapaian para siswa melalui berbagai layanan, salah satunya konseling individual. Layanan konseling individual merupakan unjuk kerja guru BK dalam menyelenggarakan hubungan profesional dengan individu konseli untuk mencapai tujuan perkembangan yang lebih optimal. Konseling mencakup segala pendekatan pemecahan masalah; terarah; dan rasional untuk membantu orang-orang yang normal (Neukrug, 2011). Sebagai tambahan, konseling adalah hubungan profesional yang memberdayakan individu atau kelompok untuk mencapai tujuan kesehatan mental; kesejahteraan; pendidikan; dan karier (CACREP, 2014). Melalui hubungan konseling, konselor akan mampu membantu konseli dalam mencapai tujuan di bidang pribadi-sosial (Hu \& Gan, 2017); akademik (Fassinger \& Good, 2017); maupun karier (Kenny, Blustein, \& Meerkins, 2018).

Hasil analisis data menunjukkan bahwa tidak ada perbedaan yang signifikan dari kinerja konselor dalam menyelenggarakan layanan konseling individual ditinjau dari latar belakang pendidikan dan pengalaman kerja sebagai guru BK. Asumsinya bahwa semakin banyak kegiatan profesionalisasi melalui sharing dengan rekan yang memiliki kepakaran atau keilmuan BK; mengikuti pelatihan layanan konseling individual; dan dorongan untuk memberikan layanan konseling individual terbaik maka semakin tinggi pula kinerja dalam menyelenggarakan konseling individual. Seperti yang diketahui bahwa ilmu pengetahuan dan teknologi mengalami perkembangan, apabila guru BK tidak up to date perkembangan BK maka dapat tertinggal dari guru BK yang bukan berlatar belakang pendidikan BK yang memiliki dorongan untuk belajar mengembangkan layanan BK secara optimal.

Profesionalitas konselor tidak hanya dilihat dari latar belakang pendidikan dan pengalaman bekerja sebagai konselor. Konselor yang tidak berlatar pendidikan BK dapat berproses ketika ia menjadi guru BK dengan mempelajari dan menerapkan teori konseling secara sungguh-sungguh dan bertahap. Guru BK yang tidak berlatar belakang pendidikan S1 BK, dapat melakukan pengembangan kegiatan profesional di bidang layanan konseling individual dengan mengikuti berbagai pelatihan dan aktivitas keprofesionalan layanan konseling individual (Stein \& DeBerard, 2010).

Mengenai pengalaman kerja sebagai guru BK, dapat diakui bahwa profesionalitas guru BK juga dapat dilihat dari lamanya mengabdi. Akan tetapi dapat ditelusuri secara lebih integral dan komprehensif bahwa tidak selalu semakin lama bekerja, semakin tinggi pula kinerja dalam menyelenggarakan layanan konseling individual. Guru BK yang baru memiliki sedikit pengalaman kerja namun memiliki passion tinggi untuk menyelenggarakan layanan konseling individual, maka akan tinggi pula kinerjanya (Sumerlin \& Littrell, 2011).

Guru BK yang baru biasanya menunjukkan kekhawatiran yang paling besar dalam pelatihan dan persiapan, kewajiban hal-hal yang bersifat non-konseling, menemukan posisi konseling, dan keefektifan mengenai kompetensinya (Cavazos, Javier, Alvarado, Rodriguez, \& Iruegas, 2009). Kekhawatiran tersebut memang dapat mengurangi keefektifan dalam kinerja, namun kekhawatiran tersebut akan hilang apabila guru BK mampu berproses sebagai guru BK profesional di sekolah dalam menyelenggarakan layanan konseling individual. Proses yang dilalui oleh guru BK untuk menemukan kenyamanan sehingga dapat menunjukkan kinerja yang berkualitas dalam menyelenggarakan konseling individual sangat beragam. Berdasarkan hasil dari penelitian ini, dapat diketahui bahwa sebagian besar guru BK dapat dengan lebih cepat merespon terhadap tugas dan perannya dalam menyelenggarakan konseling individual di sekolah.

Guru BK yang tidak memiliki latar belakang BK namun tetap relevan dengan rumpun keilmuan BK seperti Psikologi dan Psikologi Pendidikan dapat melalui kegiatan profesionalisasi in-job training. Hasil penelitian ini menunjukkan bahwa kepuasan sebagai guru BK dan motivasi tinggi untuk berproses dalam kegiatan profesionalisasi sebagai konselor sangat penting. Sebuah penelitian menunjukkan bahwa ada hubungan yang signifikan antara kepuasan dan motivasi kerja dengan tingginya kinerja (Octaviannand, 
Pandjaitan, \& Kuswanto, 2017). Apabila kepuasan dan motivasi kerja lebih tinggi, maka performa kerja juga lebih tinggi, dan jika kepuasan dan motivasi kerja rendah, hal ini membawa pada kinerja yang rendah pula.

Guru BK yang dikategorikan sebagai guru BK baru atau memiliki pengalaman kerja yang lebih singkat daripada guru BK senior juga memiliki kepuasan kerja sebagai guru BK dan motivasi kerja yang tinggi untuk menjalankan peran sebagai guru BK. Hal ini tidak bertentangan dengan paradigma guru BK profesional yang merupakan orang terlatih dan terakreditasi secara profesional untuk menyelenggarakan konseling dan psikoterapi (Jones, 2003). Pendapat ini tidak dilihat semata-mata dari pengalaman kerja sebagai guru BK, melainkan pengalaman-pengalaman yang telah dilalui dalam menjalankan tugas dan perannya sebagai konselor dalam menyelenggarakan layanan konseling individual.

Tugas dan peran guru BK sangat penting. Guru BK berperan sebagai salah satu komponen student support services, yang mendorong perkembangan aspek pribadi; sosial; karier; dan akademik siswa, melalui pengembangan berbagai program layanan kepada siswa, baik dalam layanan dasar; layanan perencanaan individual; layanan responsif; maupun dukungan sistem (ABKIN, 2007). Bahkan dalam jalannya pendidikan di sekolah, guru BK berperan sebagai pemimpin yang berkaitan dengan pendidikan (Ford \& Nelson, 2007).

Guru BK bekerja di latar pendidikan formal, baik di tingkat sekolah dasar; sekolah menengah; maupun pendidikan tinggi yang menyediakan kompetensi pribadi-sosial; akademik; dan karier bagi semua siswa, walaupun siswa berbakat sekalipun melalui program BK (Wood, 2009). Pendapat tersebut sesuai dengan ASCA (2012), yang menyatakan bahwa guru BK berperan dalam mengadvokasi setiap perkembangan akademik; karier; kesiapan pendidikan; serta kesuksesan pribadi-sosial siswa. Guru BK juga menjadi fasilitasi kesuksesan akademik siswa, serta menjadi anggota pemecahan masalah dari sumber daya tim sekolah (Hann-Morrison, 2011). Konselor harus mempunyai keterampilan untuk memberikan intervensi langsung maupun tidak langsung dalam merencanakan, mengarahkan, dan menerapkan program pencegahan, dan melayani sebagai advokat siswa. Guru BK mempunyai peran dan fungsi yang jelas.

Temuan dari penelitian ini dapat membuktikan bahwa guru BK memiliki peran dan tugas untuk memberikan layanan pendukung bagi perkembangan pribadi-sosial; akademik; dan karier siswa yang tidak hanya melihat pada latar belakang pendidikan dan lamanya pengalaman bekerja, namun juga pada motivasi untuk memberikan layanan; kesiapan mengabdi; kepuasan terhadap pekerjaan, dan kesempatan terhadap akses kegiatan profesionalisasi seperti pertemuan rapat keilmuan; seminar; pelatihan; magang; pendidikan profesi guru BK, atau kegiatan pengembangan keilmuan lainnya.

\section{SIMPULAN}

Pengalaman bekerja dan latar belakang pendidikan guru BK tidak memiliki pengaruh yang signifikan terhadap kinerjanya dalam menyelenggarakan layanan konseling individual di sekolah. Profesionalisasi hendaknya dilakukan oleh seluruh guru BK, baik yang telah lama bekerja atau senior maupun yang masih baru atau junior. Guru BK yang berlatar belakang pendidikan S1 BK maupun yang tidak berlatar belakang S1 BK hendaknya aktif mempelajari BK dan mengembangkan keterampilannya dalam menyelenggarakan konseling individual di sekolah lewat rapat keilmuan; seminar; pelatihan; magang; pendidikan profesi guru BK, atau kegiatan pengembangan keilmuan lainnya.

\section{DAFTAR RUJUKAN}

ABKIN. (2007). Penataan Pendidikan Profesional Konselor dan Layanan Bimbingan dan Konseling dalam Jalur Pendidikan Formal (Naskah Akademik). Bandung: ABKIN.

ASCA. (2012). ASCA School Counselor Competencies. Diambil 13 November, 2015, dari https://www. schoolcounselor.org/asca/media/asca/home/SCCompetencies.pdf

ASCA. (2008). Who are School Counselors? Diambil dari http://www.schoolcounselor.org/files/ WhoAreSchoolCounselors.pdf

Barida, M., \& Sutarno, S. (2016). Pengembangan Instrumen Evaluasi "Self Evaluation" dan "Peer Evaluation" Layanan Konseling Individual di Sekolah bagi Konselor. Jurnal Konseling dan Pendidikan, 4(2), 110-117. https://doi.org/10.29210/17200 
Barida, M., \& Sutarno, S. (2018). Studi Komparasi Kinerja Konselor dalam Layanan Konseling Individual Berdasarkan Self Evaluation dan Peer Evaluation. Jurnal Kajian Bimbingan dan Konseling, 3(1), 33-40.

CACREP. (2014). Why Become a Professional Counselor? Diambil dari https://www.cacrep.org/home/whybecome-a-professional-counselor/

Cavazos, Javier, J., Alvarado, V. I., Rodriguez, I., \& Iruegas, J. R. (2009). Examining Hispanic Counseling Students' Worries: A Qualitative Approach. Journal of School Counseling, 7(12).

Cronin, S. (2018). Does Having a School Counselor Matter?: A Dissertation Investigating School Counseling in Minnesota. University of Minnesota.

Epstein, J. L., \& Van Voorhis, F. L. (2010). School Counselors' Roles in Developing Partnerships with Families and Communities for Student Success. Professional School Counseling, 14(1), 1-14. https://doi. org/10.1177/2156759X1001400102

Fassinger, R. E., \& Good, G. E. (2017). Academic Leadership and Counseling Psychology: Answering the Challenge, Achieving The Promise. The Counseling Psychologist, 45(6), 752-780. https://doi. org/10.1177/0011000017723081

Ford, A. D., \& Nelson, J. A. (2007). Secondary School Counselors as Educational Leaders: Shifting Perceptions of Leadership. Journal of School Counseling, 5(19).

Geldard, K., \& Geldard, D. (2009). Counselling Children : A Practical Introduction. London: Sage Publications.

Hann-Morrison, D. (2011). The Varied Roles of School Counselors in Rural Settings. Georgia School Counselors Association Journal, 18(1), 26-33.

Hayslip Jr, B., Schneider, L. J., \& Shore, R. J. (1993). Accuracy of Counselor Age Estimates and Satisfaction with Counseling among Younger and Older Women. Journal of Applied Gerontology, 12(1), 100-113.

Hu, W., \& Gan, X. (2017). Influence on Confident Personality of College Students with Early Left-behind Experiences and Peer Counseling. Dalam Proceedings of the 2017 International Conference on Innovations in Economic Management and Social Science (IEMSS 2017). Paris, France: Atlantis Press. https://doi. org/10.2991/iemss-17.2017.179

Jones, R. N. (2003). Basic Counseling Skills: A Helper's Manual. London: Sage Publications.

Joy, R. M., Hesson, J. B., \& Harris, G. E. (2011). Preservice Teacher Perceptions of School Counsellor Responsibilities/Perceptions des responsabilités du conseiller scolaire chez les professeurs futurs. Canadian Journal of Counselling and Psychotherapy (Online), 45(4), 386-405.

Jumail, J. (2013). Kompetensi Profesional dalam Perspektif Guru BK dan Peranannya Terhadap Pelayanan Bimbingan dan Konseling di SMA Negeri se-Kota Padang. Konselor, 2(1), 250-255. https://doi. org/10.24036/02013211075-0-00

Kenny, M. E., Blustein, D. L., \& Meerkins, T. M. (2018). Integrating Relational Perspectives in Career Counseling Practice. The Career Development Quarterly, 66(2), 135-148. https://doi.org/10.1002/cdq.12128

Kozlowski, K. A. (2013). Integrating School Counseling Core Curriculum into Academic Curriculum. Journal of School Counseling, 11(5), 1-35.

Leedy, P. D., \& Ormrod, J. E. (2005). Practical Research. Pearson Custom.

Lodico, M. G., Spaulding, D. T., \& Voegtle, K. H. (2010). Methods in Educational Research: From Theory to Practice (Vol. 28). John Wiley \& Sons.

Mayes, R. D., Dollahide, C. T., \& Young, A. (2018). School Counselors as Leaders in School Turnaround. Journal of Organizational and Educational Leadership, 4(1), 1-24.

Munro, H. (2007). The Implications of Teacher Perceptions of Career Guidance Programs and The Impact on Student Career Decisions. Georgia School Counselors Association Journal, 14, 6-13.

Neukrug, E. (2011). The World of The Counselor: An Introduction to The Counseling Profession. Nelson Education.

Octaviannand, R., Pandjaitan, N. K., \& Kuswanto, S. (2017). Effect of Job Satisfaction and Motivation towards Employee's Performance in XYZ Shipping Company. Journal of Education and Practice, 8(8), 72-79.

Olguin, D. L., \& Keim, J. (2009). Using Stakeholders as Career Bridges to Advance Students' Academic Performance: How Would You Like Your Stake? Journal of School Counseling, 7(22), 1-22.

Pankhurst, K. V. (2010). Learning by Experience, Work and Productivity: Theory and Empirical Evidence. Journal of Vocational Education \& Training, 62(2), 103-122. https://doi.org/10.1080/13636821003690504

Purwanto, A., Rosra, M., \& Yusmansyah, Y. (2014). Analisis Kinerja Guru Pembimbing dalam Penyusunan Program Bimbingan dan Konseling. ALIBKIN (Jurnal Bimbingan Konseling), 3(3).

Rock, W. D., Remley, T. P., \& Range, L. M. (2017). Principal-Counselor Collaboration and School Climate. NASSP Bulletin, 101(1), 23-35. 
Sherwood, H. (2010). Utilizing Staff Perceptions to Guide and Shape Future Program Planning. Georgia School Counselors Association Journal, 17(1), 15-25.

Stein, D. M., \& DeBerard, S. (2010). Does Holding a Teacher Education Degree Make a Difference in School Counselors' Job Performance? Journal of School Counseling, 8(25).

Studer, J. R., Diambra, J. F., Breckner, J. A., \& Heidel, R. E. (2011). Obstacles and Successes in Implementing the ASCA National Model in Schools. Journal of School Counseling, 9(2).

Sugiharto, D. Y. P. (2001). Peran dan Kinerja Pembimbing dalam Peningkatan Mutu Layanan Bimbingan dan Konseling.

Sumerlin, T., \& Littrell, J. (2011). The Heart of the School Counselor: Understanding Passion Over The Span of A Career. Professional School Counseling, 14(4), 278-285. https://doi.org/10.5330/PSC.n.2011-14.278

Wood, S. (2009). Counseling Concerns of Gifted and Talented Adolescents: Implications for School Counselors. Journal of School Counseling, 7(1).

Yuksel-Sahin, F. (2009). The Evaluation of Counseling and Guidance Services Based on Teacher Views and Their Prediction Based on Some Variables. International Journal of Instruction, 2(1), 59-76. 